\title{
INHIBITION OF LUMINOUS VIBRIO HARVEYI BY "GREEN WATER" OBTAINED FROM TANK CULTURE OF TILAPIA, OREOCHROMIS MOSSAMBICUS
}

\author{
Fredson H. HUERVANA ${ }^{1}$, Joana Joy Y. DE LA CRUZ ${ }^{1}$, \\ Christopher Marlowe A. CAIPANG ${ }^{1,2 *}$ \\ ${ }^{1}$ Institute of Aquaculture, College of Fisheries and Ocean Sciences, \\ ${ }^{2}$ National Institute of Molecular Biology and Biotechnology, University of the Philippines in the Visayas, \\ Philippines
}

Huervana F.H., de la Cruz J.J.Y., Caipang C.M.A. 2006. Inhibition of luminous Vibrio harveyi by "green water" obtained from tank culture of tilapia, Oreochromis mossambicus. Acta Ichthyol. Piscat. 36 (1): $17-23$.

Background. Luminous vibriosis caused by Vibrio harveyi, is a serious disease problem in shrimp aquaculture. The use of "green water", a technique that involves the stocking of tilapia, Oreochromis in the reservoir for the production of green microalgae, Chlorella is believed to help in the reduction of the incidence of luminous vibriosis. Though most shrimp farmers have been using Mozambique tilapia, Oreochromis mossambicus for the production of "green water", the mechanism involved in the efficiency of using this fish species in reducing luminous vibriosis remains unknown and is largely based on speculations. It was for this reason that the present experiment was conducted. The aim of the study was to determine the antibacterial activity of "green water" obtained from tank culture of Oreochromis mossambicus against Vibrio harveyi under laboratory conditions.

Materials and Methods. "Green water" collected from broodstock and juvenile tanks of Oreochromis mossambicus as well as water from a commercial shrimp pond, and filtered boiled seawater were inoculated with Vibrio harveyi. Luminous bacteria were counted in nutrient agar, while presumptive and green colony-forming vibrios were determined on thiosulfate-citrate bile salt (TCBS). The experiment was carried out for one week.

Results. Luminous bacteria were not detected, and the presumptive and the green colony-forming vibrios were generally lowest in "green water" obtained from the broodstock tank. Luminous bacteria in "green water" obtained from juvenile tank were not detected starting day 5 , indicating delayed inhibition.

Conclusion. The present findings show that "green water" from broodstock tank of O. mossambicus has the ability to inhibit luminous vibriosis over a one-week period, and that broodstock are a better source of "green water" than juveniles in controlling luminous vibriosis.

Keywords: green water, Vibrio harveyi, luminous vibriosis, shrimp, tilapia, fish

\section{INTRODUCTION}

Bacterial diseases caused by members of the genus Vibrio are often the limiting factor in penaeid shrimp culture operations worldwide (de la Peña et al. 2001). Luminescent vibriosis due to Vibrio harveyi has been reported to cause mass mortalities in tiger shrimp, Penaeus monodon, reared in hatcheries and grow-out culture ponds in the Philippines (Lavilla-Pitogo and de la Peña 1998, de la Peña et al. 2001). V. harveyi is one of the 11 Vibrio species reported to be infecting cultured penaeid shrimps in Asia (Lavilla-Pitogo 1995), it is believed to be the most dominant species of luminescent Vibrio present in shrimp ponds in the Philippines with an incidence rate of $65.5 \%$ (de la
Peña et al. 2001). Heavy mortality associated with massive bacterial infection in the digestive organ of the shrimp has been observed among pond cultured P. monodon especially in the first 45 days of culture. The target organ of infection is the hepatopancreas exhibiting severe and diffuse inflammation throughout the hepatopancreas (Lavilla-Pitogo and de la Peña 1998). Mortality in most case exceeded $70 \%$ resulting in the termination of rearing activities and the collapse of shrimp farming industry in the Philippines (de la Peña et al. 2001).

The occurrence of luminescent vibriosis due to $V$. harveyi and its devastating impacts on the shrimp culture industry in the Philippines have led to the development of 
different techniques to control luminous bacteria in shrimp ponds. One of the techniques that had been reported to work is the green-water culture system (Anonymous 2000, Corre et al. 2000). It is an innovative technique in which the shrimp stocks are cultured in water where microalgae such as Chlorella sp. grow abundantly (Tendencia and de la Peña 2003). In this method, the reservoir is stocked with fish species that produce "green water" and subsequently pumped to shrimp grow-out ponds. In some cases, the fish are cultured in cages inside shrimp ponds. The species most frequently used in the green water culture system is the jewel tilapia, Tilapia hornorum. This fish species is a hybrid and has been polycultured with shrimp to control the growth of luminous bacteria. It has been reported that when these fish are stocked at a biomass of $3.0 \mathrm{t} \cdot \mathrm{ha}^{-1}$, the luminous bacteria level of the culture water is very low or could not be detected (Anonymous 2000).

Tendencia and de la Peña (2003) investigated the components of the green water system on their effects on the population of luminous bacteria. The result of the experiment suggest that both components of the green water system, the tilapia water alone and / or Chlorella alone, are effective against luminous bacteria over a short period of time, 6 and 3 days, respectively. In a follow-up experiment, Tendencia et al. (2004) reported that the direct inhibitory action of the presence of $T$. hornorum itself is one of the major factors that make the green-water culture system or finfish integrated shrimp culture effective in the control of luminous $V$. harveyi bacteria in the water. Results of the study showed that stocking of tilapia not lower than $300 \mathrm{~g} \cdot \mathrm{m}^{-3}$ efficiently reduced the $V$. harveyi count in the water stocked with shrimp at a density of $80 \mathrm{~g} \cdot \mathrm{m}^{-3}$.

Similarly, the ability of the "green water" during the grow-out culture of tiger shrimp to prevent outbreaks of luminous vibriosis was investigated by Lio-Po et al. (2005) through screening of associated isolates of bacteria, fungi, phytoplankton, and fish skin mucus for anti-luminous Vibrio metabolites. They showed that effectiveness of the "green water" in preventing outbreaks of luminous vibriosis in shrimp grow-out ponds can be attributed to the presence of anti-luminous Vibrio factors in the bacteria, fungi phytoplankton microbiota, and the skin mucus of tilapia (Lio-Po et al. 2005).

Oreochromis mossambicus or Mozambique tilapia grow well in ponds at salinities from 32 to $40 \mathrm{ppt}$ (Popper and Lichatowich 1975), surviving at 0-120 ppt (Goldstein 1973) and spawning at 34 ppt (Liao and Chang 1983). They appear to grow better in brackish water than in very low or high salinities (Payne et al. 1988) and attain a maximum weight of $850 \mathrm{~g}$ in one year under favourable conditions (Bardach et al. 1972). Although some shrimp farm operators use Mozambique tilapia to produce "green water" and believe its effectiveness against $V$. harveyi, there have been no studies conducted to prove such claim. This study aimed to verify the effectiveness of "green water" obtained from $O$. mossambicus against $V$. harveyi and to determine if the use of $O$. mossambicus is a poten- tial alternative to T. hornorum in the green water culture system.

\section{MATERIALS AND METHODS}

The "green water" was obtained from broodstock and juvenile outdoor tanks of $O$. mossambicus maintained at the University of the Philippines in the Visayas, Brackishwater Aquaculture Center. Broodstock tank contained tilapias $(30-40 \mathrm{~g})$ at a stocking density of $500 \mathrm{~g} \cdot \mathrm{m}^{-3}$ with salinity of $15 \mathrm{ppt}$. The juvenile tank was stocked with tilapia fingerlings $(1-2 \mathrm{~g})$ at a density of $450 \mathrm{~g} \cdot \mathrm{m}^{-3}$ and with salinity of $14 \mathrm{ppt}$.

Pond water was taken from a commercial pond stocked with $P$. monodon ( 20 ind. per $\mathrm{m}^{2}$ ) using a closed bioaugmented culture system at day 87 of culture. The pond was located at the Brackishwater Aquaculture Center and has a salinity of $26 \mathrm{ppt}$.

The pathogen Vibrio harveyi (0728-26 isolate) was obtained from the water of a commercial semi-intensive shrimp farm located in Central Philippines. Polymerase chain reaction (PCR) technique was used to confirm the identity of the pathogen (Maeda et al. 2002). A single colony of Vibrio harveyi was inoculated in nutrient broth and cultured overnight at $25^{\circ} \mathrm{C}$ with mild shaking. The density of the bacteria was determined by spectrophotometric reading at OD600 following the procedures outlined by Sarmasik and Chen (2003).

Glass flasks with a capacity of $1 \mathrm{~L}$ were filled with 750 $\mathrm{mL}$ of "green water" collected from the broodstock and juvenile tanks and pond water. Containers filled with filtered boiled seawater served as negative control. Each container was provided with continuous aeration and lighting. The set-up was placed at the Microbiology Laboratory of the Institute of Aquaculture, University of the Philippines in the Visayas.

Six $h$ after stocking of water, the containers were inoculated with $V$. harveyi to a final density of $10^{3} \mathrm{cfu} \cdot \mathrm{mL}^{-1}$. The following formula was used to determine the volume of bacterial suspension to be added into the containers to yield a desired density of $10^{3} \mathrm{cfu} \cdot \mathrm{mL}^{-1}$.

Two experimental runs maintained for 7 days were carried out. Triplicates per treatment were undertaken for each experimental run.

Water samples for bacterial and phytoplankton counts were taken in each container $1 \mathrm{~h}$ before inoculation of $V$. harveyi, $24 \mathrm{~h}$ after and every other day until termination on the 7 th day.

Samples $(10 \mathrm{~mL})$ for bacteriological count were collected using autoclaved $\left(121^{\circ} \mathrm{C}, 15 \mathrm{~min}\right)$ bottles. One $\mathrm{mL}$ of the water sample was serially diluted 10 -fold up to the 5 th dilution using autoclaved $1 \%$ saline solution. Representative dilutions were plated in three replicates onto nutrient agar (NA; Merck) with $1.5 \% \mathrm{w} / \mathrm{v}$ (weight/volume) sodium chloride $(\mathrm{NaCl})$ for the total bacterial count and thiosulfate citrate bile salt sucrose agar (TCBS; BBL) for presumptive Vibrio count. Agar plates were incubated for $18-24 \mathrm{~h}$ at room temperature $\left(\mathrm{ca} .30^{\circ} \mathrm{C}\right)$. Total bacterial (counted on NA plates) and presumptive Vibrio 
(counted on thiosulfate-citrate bile salt agar TCBS) counts were determined after incubation. Luminous bacteria were counted on NA plates in a darkened room for observation of luminescence.

Water samples $(5 \mathrm{~mL})$ for phytoplankton analysis were taken from the collected "green water" and pond water. No phytoplankton samples were taken from the control since filtered boiled seawater was used. Phytoplankton estimation, characterization and identification followed the procedures of Bold and Wynne (1985). Count estimates were made with standard methods using a Neubauer haemocytometer counting chamber.

Results of the bacterial counts were analyzed using analysis of variance (ANOVA) and Tukey test at $95 \%$ confidence level using SYSTAT version 8 (Chicago, Illinois).

\section{RESULTS}

The mean luminous bacterial counts of the water samples as counted in the dark room on NA plates are presented in Fig. 1. Luminous bacteria in the "green water" obtained from the broodstock tank were not detected after day 1 . The luminous bacterial counts in pond water and control were reduced to below detectable levels on day 3 and by day 5 in the "green water" obtained from juvenile tank. Luminous bacterial counts in the "green water" from broodstock tank were significantly different $(P<0.05)$ from other water samples on day 1 and the "green water" obtained from juvenile tank on day 3 .

There was no significant difference $(P>0.05)$ in the total bacterial counts among treatments from initial sampling until termination on day 7 . The mean total bacterial counts of the samples from four treatments are shown in Fig. 2. Total bacterial counts varied from day to day.
The presumptive Vibrio count (growth on TCBS agar) of samples from the four treatments is shown in Fig. 3. The initial presumptive Vibrio counts in "green water" obtained from juvenile tank and pond water were significantly different $(P<0.05)$ from the control and "green water" obtained from broodstock tank. Presumptive Vibrio counts in the control were significantly different $(P<$ 0.05 ) from other water samples from day 3 to day 7 . The presumptive Vibrio count was generally highest in the control and lowest in the "green water" obtained from broodstock tank.

The number of green colony-forming vibrios in the water samples is presented in Fig. 4. The number of green colonies in the "green water" obtained from broodstock tank was significantly different $(P<0.05)$ from other water samples on day 3 and continued until day 7 . The number of green colony-forming vibrios was generally highest in the "green water" obtained from juvenile tank and lowest in the "green water" obtained from broodstock tank.

The phytoplankton counts in the "green water" obtained from broodstock tank, juvenile tank and pond water are shown in Tables 1, 2, and 3, respectively. Chlorella sp. was the most abundant ( $>80 \%$ in abundance) species of phytoplankton in all treatments and was present throughout the duration of sampling.

\section{DISCUSSION}

Previous studies have shown that green water from Tilapia hornorum, Oreochromis niloticus hybrid, Chanos chanos, and Epinephelus coioides exerted significant antiluminous vibriosis effect (Tendencia et al. 2004, Tendencia et al. 2006). The present study demonstrated that

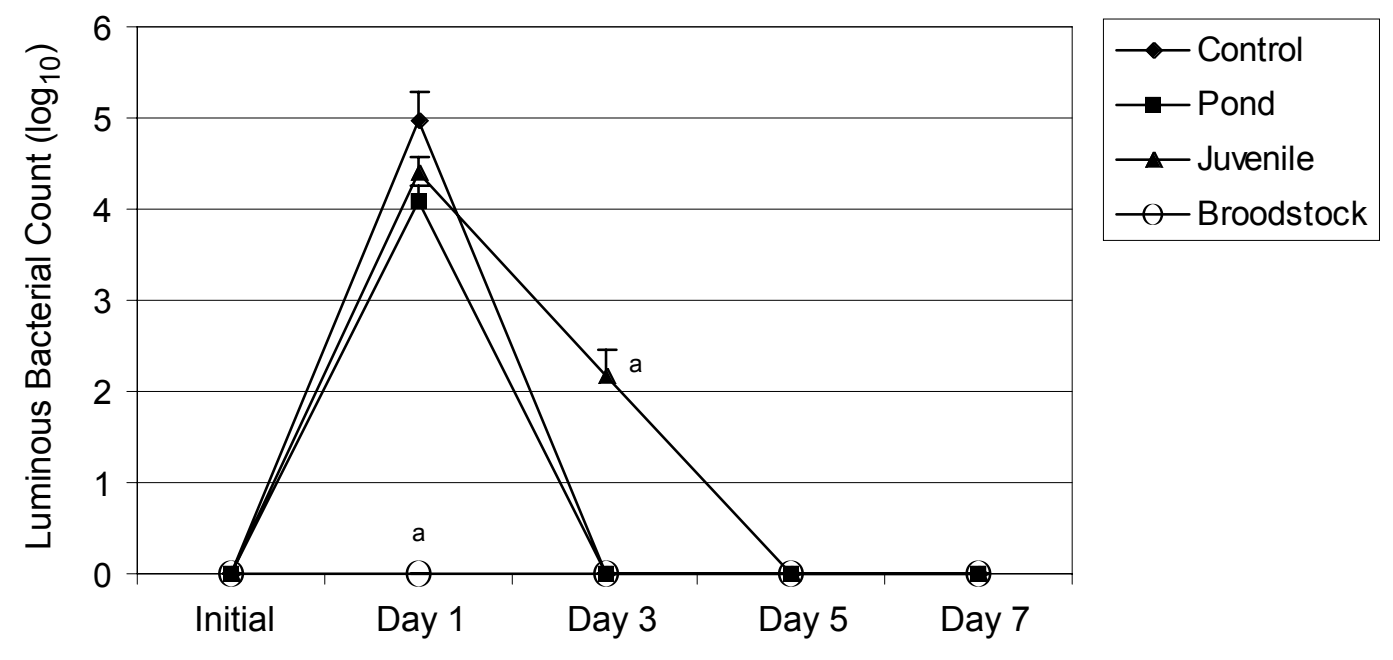

Time

Fig. 1. Luminous bacterial count in water samples after inoculation with $10^{3} \mathrm{cfu} \cdot \mathrm{mL}^{-1}$ Vibrio harveyi; line points with different letters at the same day of sampling indicate significant difference at $P<0.05(n=3)$ 


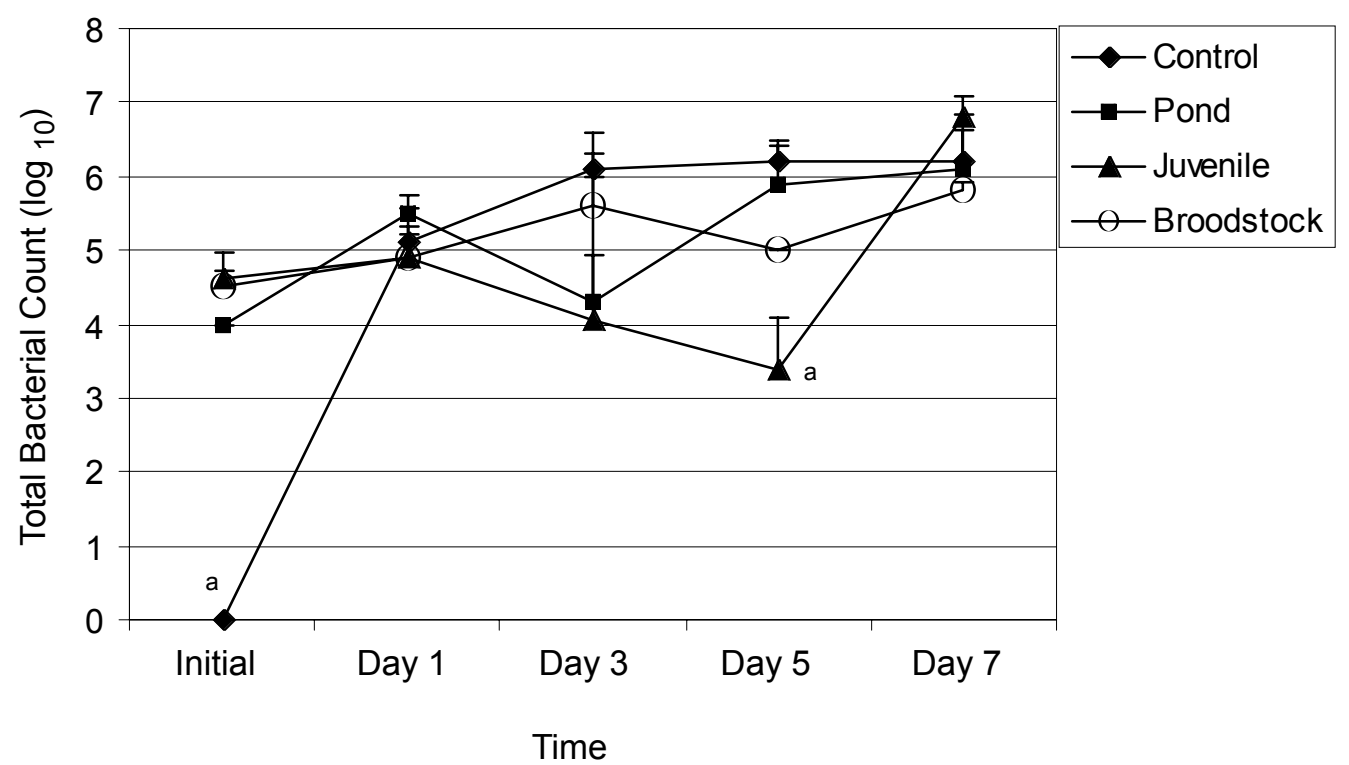

Fig. 2. Total bacterial count in water samples after inoculation with $10^{3} \mathrm{cfu} \cdot \mathrm{mL}^{-1}$ Vibrio harveyi; line points with different letters at the same day of sampling indicate significant difference at $P<0.05(n=3)$

"green water" obtained from broodstock tank of Oreochromis mossambicus possessed anti-luminous Vibrio factors and these results further add to increasing information on the role of green water in controlling luminous vibriosis in shrimp aquaculture. This gives a scientific basis on the practice of most shrimp farmers, i.e., venturing polyculture of shrimp with $O$. mossambicus or to pump water from reservoir containing $O$. mossambicus into shrimp ponds, with the purpose of controlling luminous vibriosis.

Lowest populations of presumptive Vibrio count and percentage green colony-forming vibrios in the "green water" from the broodstock tank of $O$. mossambicus are indicators that there was an effective control of $V$. harveyi in the water. Luminous bacterial count was reduced to a non-detectable level in the control and pond water on day 3 , and this is attributed to the adaptation of Vibrio harveyi to switch off bioluminescence or to enter into a non-culturable state when conditions are not favourable to their optimum growth (Ramaiah et al. 2002). In the present study, a static system was used, such that there was no chance of nutrient inflow in the system. This leads to depletion of the nutrients needed to support bacterial growth. Ramaiah et al. (2002) reported that within 6 hours of initiation of nutrient depletion, luminescence was undetectable

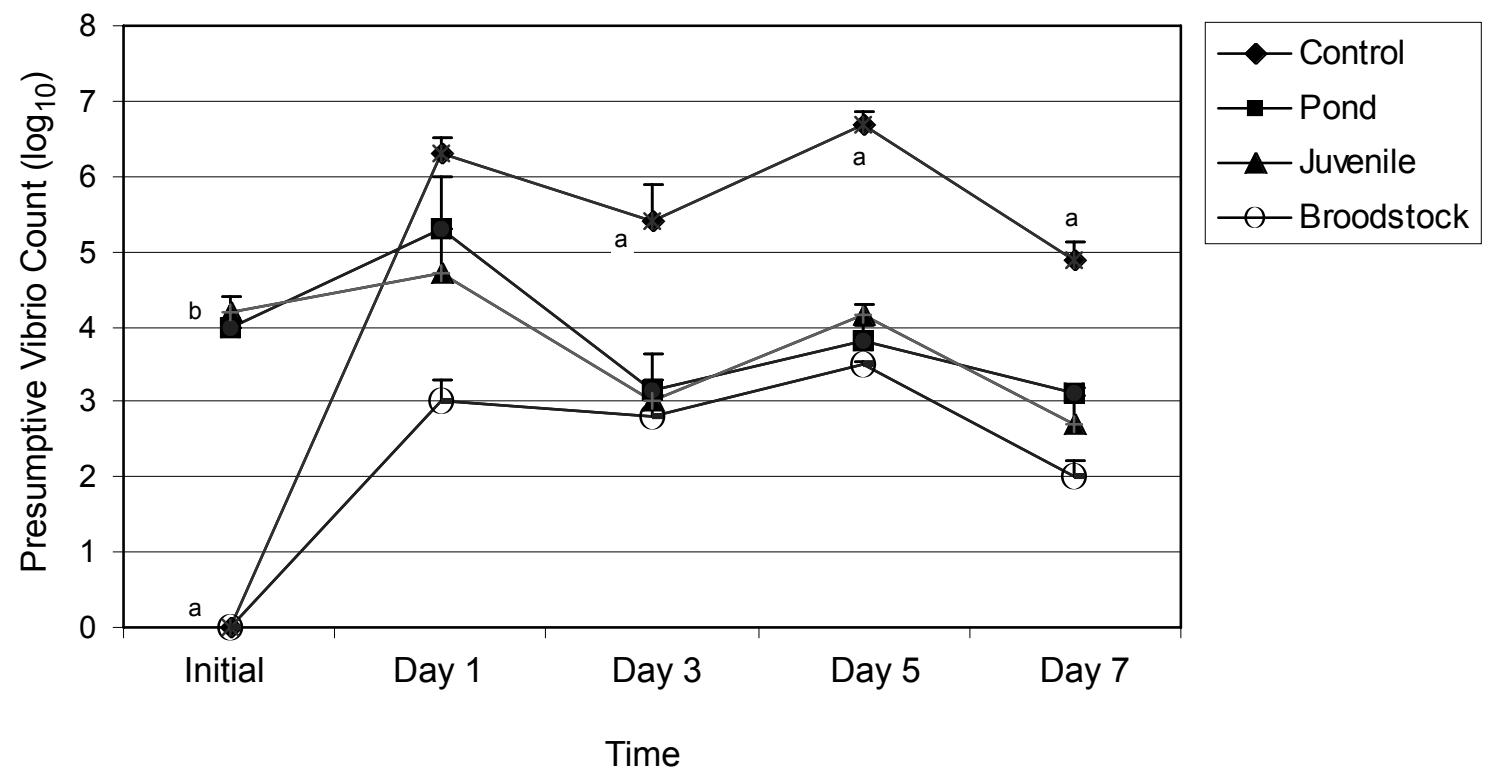

Fig. 3. Presumptive Vibrio count in water samples after inoculation with $10^{3} \mathrm{cfu} \cdot \mathrm{mL}^{-1}$ Vibrio harveyi; line points with different letters at the same day of sampling indicate significant difference at $P<0.05(n=3)$ 
from both microcosms (10 ppt and $35 \mathrm{ppt})$ of $V$. harveyi. harveyi in nutrient-depleted microcosm. It is likely that Duncan et al. (1994) observed bioluminescence to persist light production is directly proportional to cell concentraup to 5-6 days following inoculation of the water sample tion (Dunlap 1995) since in the experiment the concentrawith greater than $4 \times 10^{8}$ culturable cells $\cdot \mathrm{mL}^{-1}$ of Vibrio tion of inoculated Vibrio harveyi was $1 \times 10^{3} \mathrm{cfu} \cdot \mathrm{mL}^{-1}$

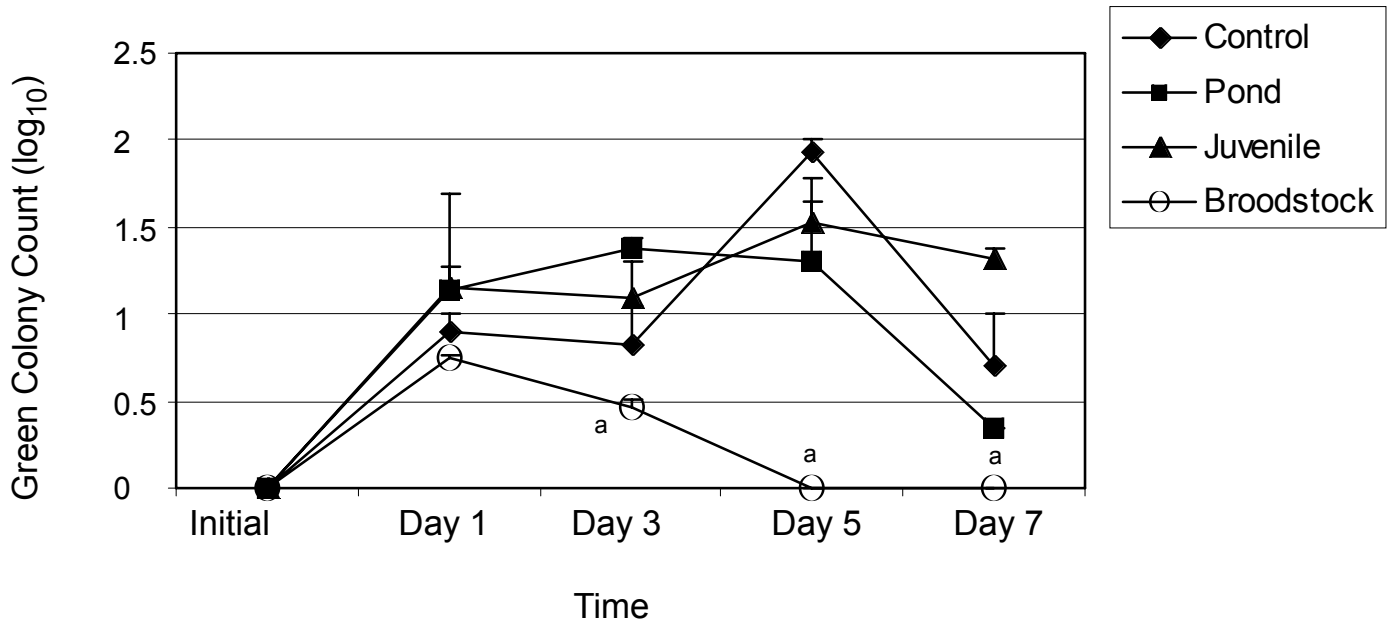

Fig. 4. Green colony-forming vibrios in water samples after inoculation with $10^{3} \mathrm{cfu} \cdot \mathrm{mL}^{-1}$ Vibrio harveyi; line points with different letters at the same day of sampling indicate significant difference at $P<0.05(n=3)$

Table 1

Algal count of "green water" obtained from broodstock tank after inoculation with $10^{3} \mathrm{cfu} \cdot \mathrm{mL}^{-1}$ Vibrio harveyi

\begin{tabular}{lccccc}
\hline \multirow{2}{*}{ Algae } & \multicolumn{5}{c}{ Cell count [cells $\mathrm{mL}^{-1}$ ] } \\
\cline { 2 - 6 } & Initial & Day 1 & Day 3 & Day 5 & Day 7 \\
\hline Chlorella sp. $^{*}$ & $3.25 \times 10^{4}$ & $3.5 \times 10^{4}$ & $1.25 \times 10^{5}$ & $1.73 \times 10^{5}$ & $2.75 \times 10^{4}$ \\
Dictyosphaerium sp. & $1.25 \times 10^{4}$ & $1.25 \times 10^{4}$ & $1.5 \times 10^{4}$ & $7.5 \times 10^{3}$ & $2.5 \times 10^{3}$ \\
Coelosphaerium sp. & $7.5 \times 10^{3}$ & 0 & 0 & 0 & 0 \\
Ankistrodesmus sp. & 0 & $2.5 \times 10^{3}$ & 0 & $5 \times 10^{3}$ & 0 \\
Chroococcus sp. & 0 & 0 & $1.25 \times 10^{4}$ & 0 & 0 \\
Gloeocapsa sp. & 0 & 0 & 0 & $5 \times 10^{3}$ & 0 \\
Golenkinia sp. & 0 & 0 & 0 & $5 \times 10^{3}$ & 0 \\
\hline
\end{tabular}

*most dominant species with $81.8 \%$ abundance

Table 2

Algal count of "green water" obtained from juvenile tank after inoculation with $10^{3} \mathrm{cfu} \cdot \mathrm{mL}^{-1}$ Vibrio harveyi

\begin{tabular}{lrcccc}
\hline \multirow{2}{*}{\multicolumn{1}{c}{ Algae }} & \multicolumn{5}{c}{ Cell count [cells $\cdot \mathrm{mL}^{-1}$ ] } \\
\cline { 2 - 6 } & \multicolumn{1}{c}{ Initial } & Day 1 & Day 3 & Day 5 & Day 7 \\
\hline Chlorella sp. ${ }^{*}$ & $1 \times 10^{5}$ & $1.6 \times 10^{5}$ & $1.3 \times 10^{5}$ & $1.1 \times 10^{5}$ & $5.5 \times 10^{4}$ \\
Microcystis sp. & $5 \times 103$ & $1.25 \times 10^{4}$ & $7.5 \times 10^{3}$ & 0 & 0 \\
Chroococcus sp. & $1.25 \times 10^{4}$ & $7.5 \times 10^{3}$ & $5 \times 10^{3}$ & 0 & 0 \\
Dictyosphaerium sp. & $1.5 \times 10^{4}$ & $2.5 \times 10^{4}$ & $7.5 \times 10^{3}$ & $1 \times 10^{4}$ & $2.5 \times 10^{3}$ \\
Golenkinia sp. & $2.5 \times 10^{3}$ & $2.5 \times 10^{3}$ & 0 & 0 & 0 \\
Scenedesmus sp. & $1.5 \times 10^{4}$ & 0 & $2.5 \times 10^{3}$ & 0 & 0 \\
Gloeocapsa sp. & $1.25 \times 10^{3}$ & 0 & $2.5 \times 10^{3}$ & 0 & $2.5 \times 10^{3}$ \\
\hline
\end{tabular}

* most dominant species with $81.4 \%$ abundance 
Algal count of pond water after inoculation with $103 \mathrm{cfu} \cdot \mathrm{mL}^{-1}$ Vibrio harveyi

\begin{tabular}{|c|c|c|c|c|c|}
\hline \multirow{2}{*}{ Algae } & \multicolumn{5}{|c|}{ Cell count $\left[\right.$ cells $\cdot \mathrm{mL}^{-1}$ ] } \\
\hline & Initial & Day 1 & Day 3 & Day 5 & Day 7 \\
\hline Chlorella sp.* & $3.5 \times 10^{5}$ & $3.06 \times 10^{5}$ & $2.5 \times 10^{5}$ & $1.7 \times 10^{5}$ & $1.6 \times 10^{5}$ \\
\hline Chroococcus sp. & $5 \times 10^{3}$ & 0 & 0 & 0 & 0 \\
\hline Oscillatoria sp. & $1.1 \times 10^{5}$ & $6.75 \times 10^{4}$ & $3 \times 10^{4}$ & $2.5 \times 10^{3}$ & 0 \\
\hline Gloeocapsa sp. & 0 & $5 \times 10^{3}$ & $2.5 \times 10^{4}$ & 0 & 0 \\
\hline
\end{tabular}

${ }^{*}$ This is the most dominant species with $83.5 \%$ abundance

and luminescence was undetectable in the pond water and control on day 3 until termination.

It is hypothesized that the kinetics of $V$. harveyi luminescence in the different treatments is attributed to the presence or absence of nutrients in the system. In the absence of tilapia no nutrient was added to treatments in the form of faeces and uneaten feeds, hence, the nutrient was depleted during the experiment. Nutrient depletion in the control and pond water may have occurred between days 2 and 3, as luminescence was not observed thereafter. Similarly, the "green water" obtained from the juvenile tank, which had luminescence on day 3 , low nutrient condition may have occurred between days 4 and 5 .

Another interesting finding was the delayed inhibition of luminescence in the "green water" obtained from the tank stocked with juveniles compared with the tank containing broodstock. It is not clear what the underlying mechanisms are involved, but it is hypothesized that the associated microflora in the "green water" or the mucus secretions produced by the fish may have an effect on the inhibition of luminous $V$. harveyi. Although, these factors were not tested in the present study, however, it was previously shown that in a related species of tilapia, T. hornorum the associated microflora in "green water" and its epidermal mucus secretions had the ability in controlling luminous vibriosis (Lio-Po et al. 2005). We can speculate that the inhibition of luminous vibriosis in "green water" obtained from the broodstock tank might be due to the quantity and quality of the mucus secretions present in the water. Fish mucus contains many antibacterial substances including anti-bacterial peptides, lysozyme, lectins, and proteases (Ellis 2001). Chong et al. (2005) characterized the protein in epidermal mucus of discus fish and showed a higher amount of parental mucus as compared to juvenile mucus. Low mucus production due to a not fully functional immune system in juvenile tilapias may not offset the antagonistic action of $V$. harveyi and this could explain the delayed inhibition of the pathogen as indicated by the persistence of luminescence in "green water" from the juvenile tank that lasted until day 3. This clearly demonstrates that the "green water" from the juvenile tilapia is not as effective as the "green water" from the broodstock tilapia in the inhibition of $V$. harveyi. Future studies will deal with testing the antimicrobial properties of the mucus of $O$. mossambicus and to delve into the molecular aspects of determining the types of genes present in the skin and underlying layers that regulate antibacterial effects.

In an earlier study, Chlorella sp. reduced the population of $V$. harveyi from $10^{3} \mathrm{cfu} \cdot \mathrm{mL}^{-1}$ to 0 after $48 \mathrm{~h}$ of exposure (Tendencia and de la Peña 2003). In addition, Lio-Po et al. (2005) reported that Leptolyngbia sp. caused a 94-100 percentage-point reduction of the luminous Vibrio population from $10^{4}$ down to $10^{1} \mathrm{cfu} \cdot \mathrm{mL}^{-1}$ and Chaetoceros calcitrans exerted complete inhibition $\left(10^{4}\right.$ down to $0 \mathrm{cfu} \cdot \mathrm{mL}^{-1}$ ) at $24 \mathrm{~h}$ post exposure. However, in the present study it was shown that though Chlorella $\mathrm{sp}$. was the most abundant phytoplankton species in the treatments tested, no apparent anti-luminous vibriosis effect was contributed by this phytoplankton. This needs further study to resolve the conflicting findings and to exactly determine the role of Chlorella in inhibiting luminous vibriosis in shrimp aquaculture.

\section{CONCLUSIONS}

1. Luminous $V$. harveyi was not detected in "green water" obtained from broodstock culture tank of $O$. mossambicus.

2. Lowest populations of presumptive and pathogenic vibrios were observed in green water from broodstock culture tank of $O$. mossambicus.

3. Broodstock of $O$. mossambicus is a better source of "green water" than juveniles in the initial control of $V$. harveyi.

4. The microalga, Chlorella sp. is the dominant species in "green water" obtained from broodstock culture tank of O. mossambicus.

5. O. mossambicus is a viable alternative to T. hornorum as a source of "green water" for the initial control of luminous vibriosis in shrimp aquaculture.

\section{ACKNOWLEDGEMENTS}

This study was supported in part by the research project, "Development of Molecular Diagnostics for Viral and Bacterial Pathogens of Shrimp Aquaculture in the Philippines" funded by the National Institute of Molecular Biology and Biotechnology (NIMBB) through the Office of 
the Vice-Chancellor for Research and Extension, University of the Philippines in the Visayas. The authors gratefully acknowledge the support of the research staff of the Brackishwater Aquaculture Center of the Institute of Aquaculture, College of Fisheries and Ocean Sciences, U.P. in the Visayas particularly to Ms. Cecilia Jaspe and Mr. Alex Gustilo.

\section{REFERENCES}

Anonymous 2000. Successful prawn culture management techniques in Negros. Negros Occidental Prawn Producers Marketing Cooperative Inc. (NPPMCI), Bacolod City.

Bardach J.E., Ryther J.H., McLarney W. 1972. Aquaculture, the farming and husbandry of freshwater and marine organisms. Reprinted by Phoenix Press Inc., Quezon City, Philippines.

Bold H., Wynne M.J. 1985. Introduction to the algae: structure and reproduction. 2nd edn. Prentice-Hall, Englewood Cliffs, New Jersey, USA.

Chong K., Ying T.S., Foo J., Jin L.T., Chong A. 2005. Characterisation of proteins in epidermal mucus of discus fish (Symphysodon spp.) during parental phase. Aquaculture 249: 469-476.

Corre jr.V.L., Janeo R., Caipang C.M., Calpe A.T. 2000. Use of probiotics and reservoir with "green water" and other tips of a successful culture. Aquaculture Asia 5: 14-18.

Duncan S., Grover L.A., Killham K., Prosser J.I. 1994. Luminescence-based detection of activity of starved and viable but nonculturable bacteria. Applied and Environmental Microbiology 60: 1308-1316.

Dunlap P. 1995. Molecular-genetic approaches to the study of symbiosis of luminous bacteria. Pp. 53-82. In: Simidu U. (ed.) Microbial symbiotic system. Ecology of miroorganisms. Vol. 21. Japan Science Society Press, Tokyo.

Ellis A.E. 2001. Innate host defense mechanisms of fish against viruses and bacteria. Developmental and Comparative Immunology 25: 827-839.

Goldstein R.J. 1973. Cichlids of the world. TFH Publication, New Jersey, USA.

Lavilla-Pitogo C.R. 1995. Bacterial diseases of penaeid shrimps: an Asian view. Pp. 67-75. In: Shariff M., Arthur J.R., Subasinghe R.P. (eds.) Diseases in Asian aquaculture II. Fish Health Section, Asian Fisheries Society, Manila.

Lavilla-Pitogo C.R., de la Peza L.D. 1998. Bacterial diseases in shrimp (Penaeus monodon) culture in the Philippines. Fish Pathology 33: 405-411.

Liao I.-C., Chang S.-L. 1983. Studies on the feasibility of red tilapia culture in saline water. Pp. 524-533. In: Fishelson L., Yaron Z. (Compilers) Proceedings of the International Symposium on Tilapia in Aquaculture. Nazareth, Israel, 8-13 May 1988. Tel Aviv, Israel.
Lio-Po G.D., Leańo E.M., Pezaranda M.M.D., Villa-Franco A.U., Sombito C.D., Guanzon jr.N.G. 2005. Anti-luminous Vibrio factors associated with the "green water" growout culture of the tiger shrimp Penaeus monodon. Aquaculture 250: $1-7$.

Maeda T., Furushita M., Itami T., Shiba T. 2002. Rapid identification of Vibrio harveyi based on the structure of ribonuclease P RNA gene. Fisheries Science 68 (Suppl. 1): 814816.

Payne I.A., Ridgway J., Hamer J.L. 1988. The influence of salt $(\mathrm{NaCl})$ concentration and temperature the growth of Oreochromis mossambicus and a red tilapia hybrid. Pp 481487. In: Pullin R.S.V., Bhukaswan T., Tonguthai K., Maclean J.L. (eds.) The Second International Symposium on Tilapia in Aquaculture. ICLARM Conference Proceedings 15. Department of Fisheries, Bangkok, Thailand, and International Center for Living Aquatic Resources Management, Manila, Philippines.

Peña L.D. de la, Pitogo C.L., Paner M.G. 2001. Luminescent vibriosis associated with mortality in pond-cultured shrimp Penaeus monodon in the Philippines: species composition. Fish Pathology 36: 133-138.

Popper D., Lichatowich T. 1975. Preliminary success in predator control of Tilapia mossambica. Aquaculture 5: 213214.

Ramaiah N., Ravel J., Straube W.L., Hill R.T., Colwell R.R. 2002. Entry of Vibrio harveyi and Vibrio fisheri into the viable but nonculturable state. Journal of Applied Microbiology 93: 108-106.

Sarmasik A., Chen T.T. 2003. Bactericidal activity of cecropin B and cecropin P1 expressed in fish cells (CHSE-214): application in controlling fish bacterial pathogens. Aquaculture 220: 183-194.

Tendencia E.A., Peña M.R. de la 2003. Investigation of some components of the greenwater system which makes it effective in the initial control of luminous bacteria. Aquaculture 218: 115-119.

Tendencia E.A., de la Peña M.R., Fermin A.C., Lio-Po G.D., Choresca jr. C.H., Inui Y. 2004. Antibacterial activity of Tilapia hornorum against Vibrio harveyi. Aquaculture 232: 145-152.

Tendencia E.A., Fermin A.C., Peña M.R. de la, Choresca jr. C.H. 2006 Effect of Epinephelus coioides, Chanos chanos, and GIFT tilapia in polyculture with Penaeus monodon on the growth of the luminous bacteria Vibrio harveyi. Aquaculture 253: 48-56.

Received: 17 October 2005 Accepted: 12 June 2006 